\title{
GLOBALISATION, TRADE OPENNESS AND FOREIGN DIRECT INVESTMENT IN ROMANIA
}

\author{
Stela Dima, Ph.D \\ "Vasile Goldis" Western University of Arad \\ e-mail:dm_stela@yahoo.com
}

(Received August 2016; Accepted October 2016)

\begin{abstract}
The paper analyses the trend of globalisation, trade openness and foreign direct investments (FDI) in Romania and the link between them in the last 25 years. Data from UNCTAD, World Bank and KOF globalisation index were used in econometrical models testing the link between globalisation, trade openness and foreign direct investment. A strong positive and statistical validated link is found between globalisation and FDI, between trade openness and FDI, and between FDI and globalisation. In the context of Romanian economy, these three phenomena are interrelated and each of them is acting to potentiate the effect of the other. Moreover, a multivariate regression analysis emphasized the dependency between globalisation index and foreign direct investment, trade openness and market capitalisation. These results can be taken into account when national policies aiming to attract FDI and stimulating export-import activities are designed.
\end{abstract}

Key words: globalisation, trade openness, foreign direct investment

JEL CODES: F60, F41, F21

\section{Introduction}

Without any doubt, globalisation is a complex phenomenon with several national or international stimulating or hindering factors and with diverse effects in the national economies and in the world economy as a whole. The process of globalisation of a national economy is clearly influenced by its economic performance, the level of openness to international trade, the financial development and the capacity to attract foreign investments. Foreign capital has played an important role in privatisation and restructuration process in Eastern European economies such as Romania.

The paper proposes an analysis of three economic phenomena: globalisation, trade openness and foreign direct investment in Romania in the last 25 years, by proving the link between them through linear econometrical models.

The paper is organised as follows. After an introduction, the first section contains a review of main studies relevant to the paper's topic, the second section presents the trends of globalisation, trade openness and foreign direct investment in Romania in the last 25 years, the third section exposed data and methodology of the study, the 
Dima S. (2016)

Globalisation, trade openess and foreign direct investment in Romania

fourth section presents the main findings of the study, the fifth section includes a short discussion of them and the final section is dedicated to conclusions.

\section{Review of relevant scientific literature}

The globalization phenomenon has a number of determinant factors: economic (trade, capital flows, financial development); technological (technologies' exports, research \&development, information society); social (population migration, educational and health systems, poverty, discrimination); cultural (freedom, acceptance, tolerance); politic (international and multilateral global cooperation, global stability and security) (Bari, 2005; Catana, 2011; Huidumac et al., 2011; Murariu, 2011).

FDI is seen as an important factor stimulating economic growth, expansion of capital stock, productivity and employment growth, innovation and technology transfer in emerging economies (Isac et al., 2011). High shares of FDI stocks as a percentage of GDP in these economies indicate that foreign capital acts as advancing factor of globalisation process (Kornecki \&Rhoades, 2007).

In Eastern and Central European countries, such as Romania, the reason for attracting FDI was to facilitate the privatisation and restructuration processes (Heimann, 2003).

Developing countries embrace globalisation due to the removal of trade barriers, expanding of market opportunities for consumers, foreign direct investment which provides more jobs, new technologies, development of capital (Kahai \&Simmons, 2005).

Inward FDI represents a means for integration of national economies with global economy (Aizenman and Noy, 2005; Adams, 2008; Méon and Sekkat, 2007; Hailu, 2010; Almsafir, Nor, and Al-Shibami, 2011; Moghaddam and Redzuan, 2012; Almfraji, Almsafir, and Yao, 2014).

FDI has noticeable effects on trade in developing countries (Farshid, Ali, and Gholamhosein, 2009) and increased inward FDI allows the openness of the economy and the foreign exchange environment to be more favorably (Fadhil and Almsafir, 2015; Al-Shawaf \&Almsafir, 2016), nevertheless trade openness has a significant impact on FDI inflows (Pradhan, 2010).

In the case of Romanian economy, globalisation is favourable for economic growth on medium and long term (Mutascu \& Fleischer, 2011), but could as well, lead to a higher income inequality (Neagu, 2014).

In the present paper, the globalization of the Romanian economy is focused on economic integration, which is decomposed by trade openness, financial integration and foreign capital level. The trade openness is measured by the share of the sum of exports and imports in total GDP, the global financial integration is 
measured by the market value of the domestic listed companies as \% of GDP and the foreign capital level is measured by the inward stock of foreign direct investment.

\section{Trends of globalisation, trade openness and foreign direct investment (FDI)} in Romania in the last 25 years

As it is shown in figure 1, the economic globalisation index for the Romanian economy evolved positively in the last 25 years, the increase was pronounced in the first 10 years, from $34.13 \%$ (1990) to $62.06 \%$ (2000), followed by a positive trend until a maximum of $76.00 \%$ in 2007. Between 2007 and 2012, the economic globalisation index decreased until 2012 and it has been followed by a positive trend in the last years.

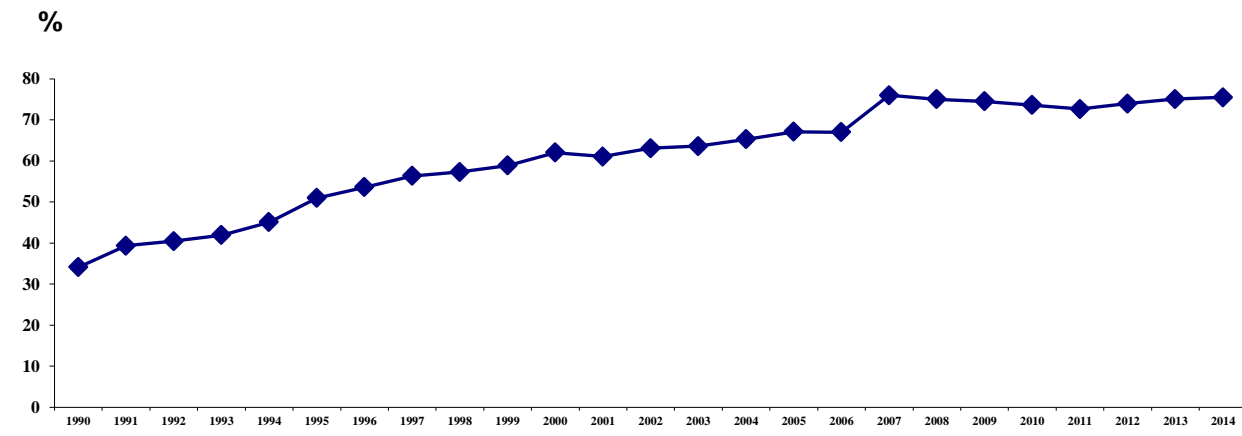

Figure 1 Evolution of economic globalisation index in Romania, 1990-2014

Source: author's computation based on KOF globalization index values

Trade openness is defined as the sum of exports and imports as a percentage of Gross Domestic Product (GDP). As a general trend in the last 25 years we can notice a duplication of the share of exports and imports in GDP between 1990 and 2014 , respectively an increase from $42.90 \%$ of GDP in 1990 to $82.17 \%$ of GDP in 2014 (Figure 2).

But there are ups and downs from the general trend (the red line), explained partly by the liberalisation of export and import activities after 1990, some political measures stimulating export activities and the propensity of economic agents to import foreign products due to their lower prices. For instance, a leap to $63.99 \%$ in 1992 is followed by a decrease and then a recovery in the following years to $65.41 \%$ in 1997 , a decline to 1998 , followed by increasing values to 2004 . The

Studia Universitatis "Vasile Goldis" Arad. Economics Series Vol 26 Issue 4/2016 ISSN: 1584-2339; (online) ISSN: $2285-3065$

Web: publicatii.uvvg.ro/index.php/studiaeconomia.Pages $41-53$ 
Dima S. (2016)

Globalisation, trade openess and foreign direct investment in Romania

economic crisis is reflected in the evolution of trade in 2009. After 2009, a positive trend is installed (Figure 2).

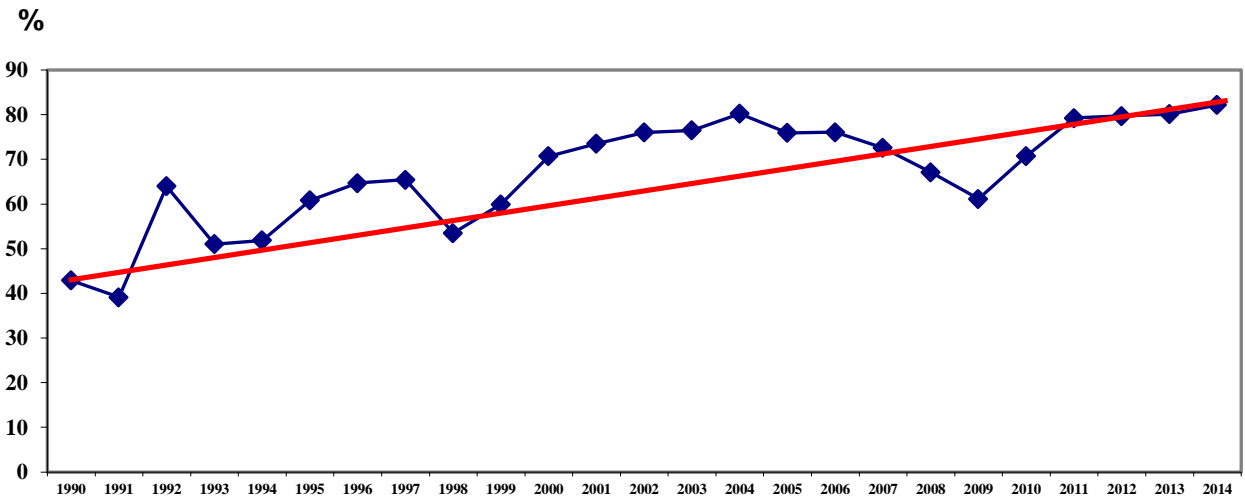

Figure 2 Evolution of trade openness in Romania, 1990-2014

Source: author's computation based on World Bank data

Attracting FDI in the Romanian economy was timid and hesitating in the first ten years after 1990 due to an inappropriate legislative framework firstly, and secondly, to the legislative incoherencies. The maximal values of FDI net inflows were registered between 2004 and 2008 (9.26\% in 2006), followed by a sharp decrease in 2009-2011(1.37\%) as an effect of global financial crisis. The recovery in the last years has been very modest (1.94\% in 2014) (Figure 3).

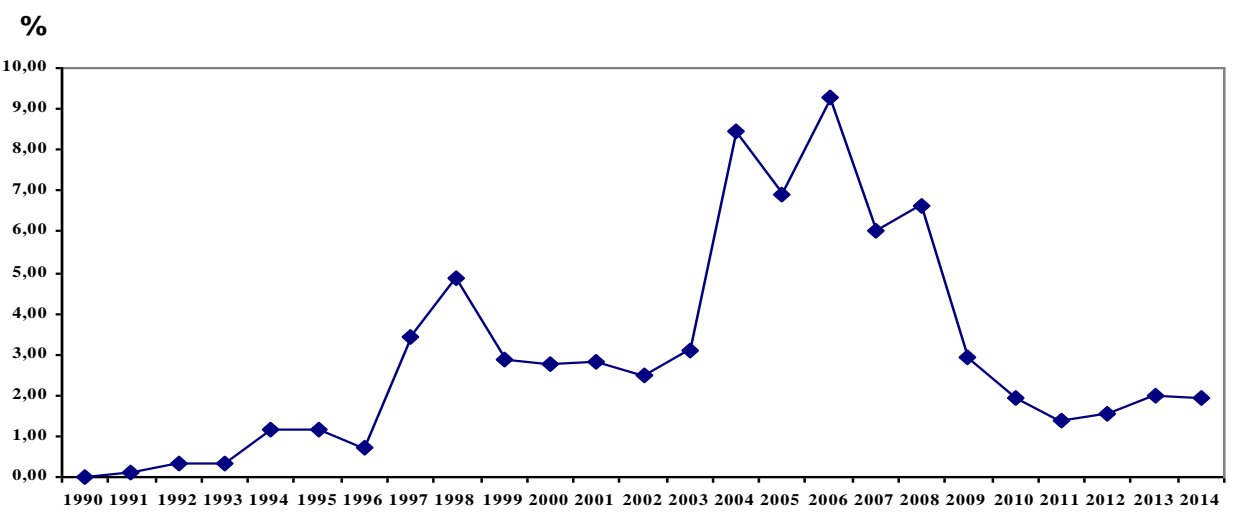

Figure 3 FDI net inflows (\% of GDP) dynamics in Romania, 1990-2014

Source: author's computation based on World Bank data 
In connection with the evolution exposed in the Figure 3, in the first ten years after 1990 the level of FDI inward stock is very low, noticeable values are registered only starting with 1999-2000. A maximal value is attained in 2013, followed by a decrease to 74731 million US dollars in 2014 (Figure 4).

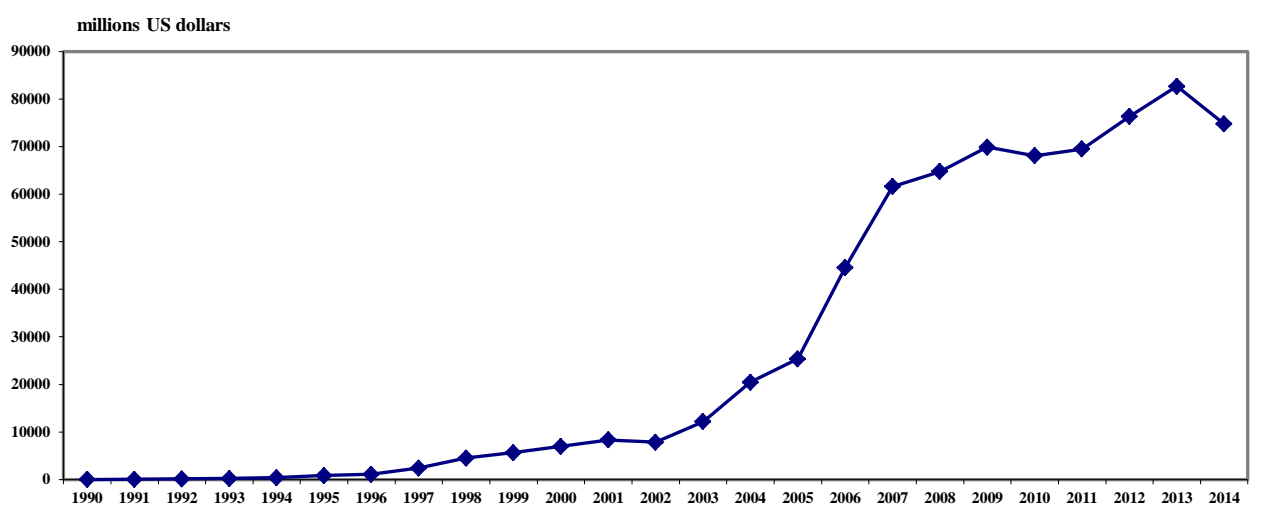

Figure 4 Evolution of FDI inward stock (million US dollars, at current prices), 1990-2014

Source: author's computation based on UNCTAD data

\section{Data and methodology of the study}

For the purpose of the study, the following data bases were explored: UNCTAD, World Bank and KOF globalisation index time series. From UNCTAD time series of FDI inward stock (in million US dollars, at current prices) and market capitalisation of listed companies as 5 of GDP were extracted for a time period of 1990-2014 and from World Bank Data Base, time series of "trade openness" were selected. The indicator "trade openness" means the sum of exports and imports as $\%$ of Gross Domestic Product (GDP). The paper uses the database of globalisation index calculated by Dreher in 2006 and updated in 2008. Dreher (2006, 2008) calculated the KOF globalisation index including three subglobalisation indexes: economic, social and political integration. From this database were extracted times series for economic component of globalisation index.

The data are annual and the time span covers the period 1990-2014, except the KOF globalisation index which stops in 2013. In regression analysis including the market capitalisation of listed companies the time span is only from 1998 to 2013 due to availability of data.

In order to highlight the connection between globalisation, trade openness and FDI inward stock, we will use the econometrical model of linear regression. 
Dima S. (2016)

Globalisation, trade openess and foreign direct investment in Romania

We assume that:

$$
G I=f(F D I)
$$

where: GI is the economic globalisation index, and

$$
T O=f(G I)
$$

where: TO is trade openess, and

$$
F D I=f(T O)
$$

and

$$
G I=f(F D I, T O, M K c a p)
$$

where MKcap is market capitalisation of listed companies as \% of GDP.

We transform (1), (2), (3) and (4) in regression equations as follows:

$$
G I=\alpha+\beta \cdot F D I+\varepsilon
$$

where: GI (economic globalisation index) is the dependent variable, $\alpha$ is a constant, $\beta$ is the regression parameter of the independent variable, FDI is the independent or explanatory variable and $\varepsilon$ is the error;

$$
T O=\delta+\varphi \cdot G I+\gamma
$$

where: $\delta$ is a constant, $\varphi$ is the regression parameter, GI is the explanatory variable and $\gamma$ is the error;

$$
F D I=\partial+\lambda \cdot T O+\mu
$$

where: FDI is the dependent variable, $\partial$ is a constant, $\lambda$ is the regression parameter and $\mu$ is the error.

We intend further to test a multivariate dependency of globalisation to FDI, TO and MKcap:

$$
G I=c_{0}+c_{1} \cdot F D I+c_{2} \cdot T O+c_{3} \cdot M K c a p+e
$$

where: FDI, TO and MKcap are explanatory variables, c0 is a constant, $c_{1}, c_{2}, c_{3}$ are regression parameters and $\mathrm{e}$ is the error.

Data were processed and equations were estimated by using E-views 8.0 software.

\section{Main findings}

The estimation results of equation 5 are displayed in Table 1.

The estimated equation 4 is the following:

$$
G I=51.22121+0.000343 \cdot F D I
$$

An increase of $10 \%$ in FDI will induce a $0.00343 \%$ increase of the globalization index, if other factors are constant. The linear regression model is statistically validated for a significance threshold of 5\%, taking into account that the values of Prob for the constant (C) and variable (FDI) are $0.000<0.05$ and the value of Fstatistic (54.811123) is higher than $F_{1,23}$ (4.28) and Prob (F-statistic) (0.0000) $<0.05$. According to the value of R-squared, we can say that in a proportion of 
Dima S. (2016)

Globalisation, trade openess and foreign direct investment in Romania

$70.44 \%$ the variation of GI is due to the variation of FDI, under caeteris paribus condition (Table 1).

Dependent Variable: GI

Table 1 Estimation of equation 5

Method: Least Squares

Sample: 19902014

Included observations: 25

\begin{tabular}{lrlrr}
\hline \hline \multicolumn{1}{c}{ Variable } & Coefficient & Std. Error & t-Statistic & Prob. \\
\hline \multicolumn{1}{c}{ CDI } & 51.22121 & 1.946665 & 26.31228 & 0.0000 \\
\hline \hline R-squared & 0.000343 & \multicolumn{1}{c}{ 4.64E-05 } & 7.403461 & 0.0000 \\
Adjusted R-squared & 0.704413 & Mean dependent var & & 60.95633 \\
S.E. of regression & 0.691561 & S.D. dependent var & & 12.92304 \\
Sum squared resid & 7.177105 & Akaike info criterion & & 6.856288 \\
Log likelihood & 1184.749 & Schwarz criterion & & 6.953798 \\
F-statistic & -83.70359 & Hannan-Quinn criter. & & 6.883333 \\
Prob(F-statistic) & 54.81123 & Durbin-Watson stat & & 0.152033 \\
\hline Source: autor & 0.000000 & & & \\
\hline
\end{tabular}

Source: author's own computation using Eviews 8.0 software

Dependent Variable: TO

Table 2 Estimation of equation 6

Method: Least Squares

Sample: 19902014

Included observations: 25

\begin{tabular}{lrlrr}
\hline \hline \multicolumn{1}{c}{ Variable } & Coefficient & \multicolumn{1}{c}{ Std. Error } & t-Statistic & Prob. \\
\hline \multicolumn{1}{c}{ GI } & 21.51264 & 7.268201 & 2.959831 & 0.0070 \\
\multicolumn{1}{c}{ GI } & 0.746322 & 0.116744 & 6.392797 & 0.0000 \\
\hline R-squared & 0.639881 & Mean dependent var & 67.00567 \\
Adjusted R-squared & 0.624224 & S.D. dependent var & 12.05705 \\
S.E. of regression & 7.391039 & Akaike info criterion & 6.915032 \\
Sum squared resid & 1256.431 & Schwarz criterion & 7.012542 \\
Log likelihood & -84.43790 & Hannan-Quinn criter. & 6.942077 \\
F-statistic & 40.86785 & Durbin-Watson stat & 1.212796 \\
Prob(F-statistic) & 0.000002 & & \\
\hline \hline
\end{tabular}

Source: author's own computation using Eviews 8.0 software

The estimated equation 6 is the following:

$$
T O=21.51264+0.746322 \cdot G I
$$

The linear regression model is statistically validated for a significance threshold of $5 \%$ due to the fact that the value of F-statistic (40.86785) $>F_{1,23}(4.28)$ and Prob (Fstatistic) (0.000002) is lower than 0.05. For both regression parameters $(\alpha$ and $\beta)$, 
Dima S. (2016)

Globalisation, trade openess and foreign direct investment in Romania

the value of Prob is less than 0.05, proving their validation. When GI increases with $10 \%$ the trade openness can increase with $7.46322 \%$. The variation of trade openness is due in a proportion of $63.98 \%$ to variation of GI under caeteris paribus condition (Table 2).

Dependent Variable: FDI

Table 3 Estimation of equation 7

Method: Least Squares

Sample: 19902014

Included observations: 25

\begin{tabular}{lrlrr}
\hline \hline \multicolumn{1}{c}{ Variable } & Coefficient & \multicolumn{1}{c}{ Std. Error } & t-Statistic & Prob. \\
\multicolumn{1}{c}{ TO } & -73104.64 & 30323.22 & -2.410847 & 0.0243 \\
\multicolumn{1}{c}{ TO } & 1514.059 & \multicolumn{1}{c}{445.6735} & 3.397237 & 0.0025 \\
\hline R-squared & 0.334129 & Mean dependent var & 28345.86 \\
S.E. of regression & 0.305178 & S.D. dependent var & 31581.06 \\
Sum squared resid & 26324.70 & Akaike info criterion & 23.27102 \\
Log likelihood & $1.59 \mathrm{E}+10$ & Schwarz criterion & 23.36853 \\
F-statistic & -288.8878 & Hannan-Quinn criter. & 23.29807 \\
Prob(F-statistic) & 11.54122 & Durbin-Watson stat & 0.295060 \\
\hline Source & 0.002475 & & \\
\hline
\end{tabular}

Source: author's own computation using Eviews 8.0 software

The estimated equation 7:

$$
F D I=-73104.64+1514.059 \cdot T O
$$

The linear regression model is statistically validated for a significance threshold of $5 \%$ due to the fact that the Prob (F-statistic) $(0.002475)<0.05$ and the value of Fstatistic (11.54122) is higher than $\mathrm{F}_{1,23}$ (4.28). For an increase with one unit of TO, FDI will increase with 1514.059 units. The variation of FDI can be attributed in a proportion of $33.41 \%$ to the variation of $\mathrm{TO}$, under caeteris paribus condition (Table 3).

The estimated equation 8 is:

$$
G I=56.53243+0.000192 \cdot F D I+0.041552 \cdot T O+0.095361 \cdot \text { MKcap }
$$

The multivariate linear regression model is statistically validated for a significance threshold of $5 \%$ due to the fact that the Prob (F-statistic) $(0.000001)<0.05$ and the value of F-statistic (49.27874) is higher than $\mathrm{F}_{0.05 ; 3 ; 12}$ (3.49). The value of Prob $(0.000)$ is lower than 0.05 for the intercept and for the coefficient of FDI, meaning that the dependency between FDI and GI is statistically validated. For an increase with one unit of FDI, GI will increase with 0.000192 units. The coefficients of other explanatory variables (TO and MKCAP) are not statistically validated as their Prob is higher than 0.05 (Table 4). 
Dima S. (2016)

Globalisation, trade openess and foreign direct investment in Romania

Dependent Variable: GI

Table 4 Estimation of equation 8

Method: Least Squares

Date: 09/28/16 Time: 07:29

Sample: 19982013

Included observations: 16

\begin{tabular}{crccr}
\hline \multicolumn{1}{c}{ Variable } & Coefficient & Std. Error & t-Statistic & Prob. \\
\hline C & 56.53243 & 5.092097 & 11.10199 & 0.0000 \\
FDI & 0.000192 & $1.92 \mathrm{E}-05$ & 10.02273 & 0.0000 \\
TO & 0.041552 & 0.075824 & 0.548001 & 0.5937 \\
MKCAP & 0.095361 & 0.107124 & 0.890191 & 0.3909 \\
\hline \hline R-squared & 0.924923 & Mean dependent var & 67.90796 \\
Adjusted R-squared & 0.906154 & S.D. dependent var & 6.471234 \\
S.E. of regression & 1.982417 & Akaike info criterion & 4.418829 \\
Sum squared resid & 47.15975 & Schwarz criterion & 4.611976 \\
Log likelihood & -31.35063 & Hannan-Quinn criter. & 4.428720 \\
F-statistic & 49.27874 & Durbin-Watson stat & 1.578232 \\
Prob(F-statistic) & 0.000001 & & \\
\hline \hline
\end{tabular}

Source: author's own computation using Eviews 8.0 software

We test further the heteroskedasticity of error by using the White test (Table 5).

As we can notice in the Table 5, F-statistic (1.855198) $<\mathrm{F}_{0.05: 16}$ (4.49) and Obs*Rsquared (11.77033) is lower than $\chi_{0.05 ; 17}^{2}(27.59)$ meaning that the null hypothesis is accepted and errors are homoskedastic. As a result, the dependency between independent variables and the dependent variable is stable.

The uni- and multivariate regression models of the explanatory variables of globalisation in the case of the Romanian economy were validated but a more detailed discussion is required, as follows.

\section{Table 5 Heteroskedasticity test}

Heteroskedasticity Test: White

\begin{tabular}{llll} 
F-statistic & 1.855198 & Prob. F(9,6) & 0.2328 \\
Obs*R-squared & 11.77033 & Prob. Chi-Square(9) & 0.2266 \\
Scaled explained SS & 3.456279 & Prob. Chi-Square(9) & 0.9434 \\
\hline
\end{tabular}

Test Equation:

Dependent Variable: RESID ${ }^{\wedge}$

Method: Least Squares

Date: 09/28/16 Time: 07:30

Sample: 19982013

Included observations: 16

DE GRUYTER

OPEN
Studia Universitatis "Vasile Goldis" Arad. Economics Series Vol 26 Issue 4/2016 ISSN: 1584-2339; (online) ISSN: $2285-3065$

Web: publicatii.uvvg.ro/index.php/studiaeconomia.Pages $41-53$ 
Dima S. (2016)

Globalisation, trade openess and foreign direct investment in Romania

\begin{tabular}{crcrr}
\hline \hline Variable & Coefficient & Std. Error & t-Statistic & Prob. \\
\hline \hline C & 81.34727 & 90.26521 & 0.901203 & 0.4022 \\
FDI^2 & $-5.59 \mathrm{E}-09$ & $5.79 \mathrm{E}-09$ & -0.965112 & 0.3718 \\
FDI*TO & $-8.57 \mathrm{E}-07$ & $8.13 \mathrm{E}-06$ & -0.105464 & 0.9194 \\
FDI*MKCAP & $2.08 \mathrm{E}-05$ & $2.06 \mathrm{E}-05$ & 1.013007 & 0.3502 \\
FDI & 0.000402 & 0.000789 & 0.509749 & 0.6284 \\
TO^$^{\wedge}$ & 0.017276 & 0.022884 & 0.754941 & 0.4789 \\
TO*MKCAP & -0.003226 & 0.072169 & -0.044699 & 0.9658 \\
TO & -2.364466 & 2.896280 & -0.816380 & 0.4455 \\
MKCAP^2 & 0.012876 & 0.060689 & 0.212159 & 0.8390 \\
MKCAP & -0.781557 & 5.529896 & -0.141333 & 0.8922 \\
\hline \hline R-squared & 0.735645 & Mean dependent var & 2.947484 \\
Adjusted R-squared & 0.339113 & S.D. dependent var & 3.110497 \\
S.E. of regression & 2.528676 & Akaike info criterion & 4.962440 \\
Sum squared resid & 38.36522 & Schwarz criterion & 5.445308 \\
Log likelihood & -29.69952 & Hannan-Quinn criter. & 4.987166 \\
F-statistic & 1.855198 & Durbin-Watson stat & 2.385522 \\
Prob(F-statistic) & 0.232754 & & \\
\hline SOutce: author's & & &
\end{tabular}

Source: author's own computation using Eviews 8.0 software

\section{Discussion}

The three investigated variables (GI, FDI and TO) are evolving in relationship with each other as it is shown in the Figure 5. The interconnection is statistically validated for a significance threshold of $5 \%$.

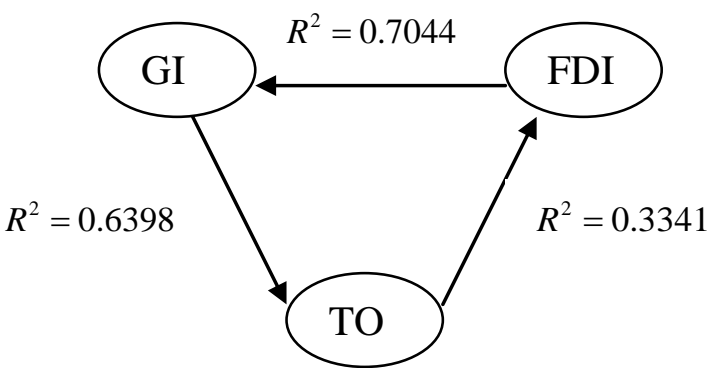

Figure 5 The interlink between GI, FDI and TO

Source: author's own findings

In this virtuous circle, FDI influence GI in a proportion of $70.44 \%$, which, in turn, stimulates TO, explaining its increase in a share of $63.98 \%$ and finally, TO is positively associated with FDI and explains its variation in a proportion of $33.41 \%$, when other factors are remaining constant. Globalisation is stimulated by the foreign direct investments and it could be called "a vehicle of globalization" (Isac 
et al., 2011; Huidumac-Petrescu et al., 2011) and promotes the trade, at its turn, by inciting its volume. Trade openness is driven by globalisation dynamics and is responsible for FDI developing.

In a multivariate analysis of GI (globalisation index), the correlation between FDI and TO leads to the nonvalidation of the coefficients variables TO and MKcap. Testing the multi-dependency of GI to FDI, TO and MKcap in a multivariate regression model conducted us to the conclusion that only the positive influence of FDI on globalisation index can be statistically validated in the case of Romanian economy, the influence of the other variables cannot be statistically proved. Thus, from our multivariate regression we cannot say very much about the multidependency of globalisation to trade openness and market capitalisation. However, due to the homoskedasticity of errors, the relationship between FDI, TO, MKcap and GI is a stable one.

\section{Conclusions}

The paper provides an analysis of the connection between FDI, globalisation and trade openness in Romania in the last 25 years.

By testing three econometrical models, a statistical positive and validated link between these three phenomena was found. Thus, the level of inward stock of FDI influenced the process of globalisation in Romania, which is positively affected by the level of trade openness (sum of exports and import as \% of GDP). In turn, the globalisation process stimulated the export and import activities in the last 25 years.

The three economic phenomena are interrelated as shown in the Figure 5. As policy implications, it is worth to take into account these interconnections in the designing of policy measures aiming to attract foreign direct investment and stimulate the export-import activities.

The dependency between globalisation index and foreign direct investment, trade openness and market capitalisation is statistically overall validated, but for trade openness and market capitalisation as explanatory variables any validation was identified.

As a limit of the study we mention the need to check the sense of the causality of the identified statistical relationships with (using, for example, the Granger causality test). Moreover, longer time series are needed to analyze the dependency of globalization index on several explanatory variables.

As further direction of research, the analysis can be extended by including other economic factors stimulating or hindering the influence of globalization process within the Romanian economy. 


\section{References}

1. Adams, S.(2008).Globalization and income inequality: Implications for intellectual property rights. Journal of Policy Modeling, 30(5), pp.725-735.

2. Aizenmann, J. and Noy, I.(2006). FDI and trade-Two-way linkages?.The Quartely Review of Economics and Finance, 46(3), pp.317-337.

3. Almfraji, M.A., Almsafir, M.K. and Yao, L.(2014). Economic Growth and Foreign Direct Investment Inflows: The Case of Qatar. Procedia-Social and Behavioral Sciences, 109, pp.1040- 1045.

4. Almsafir, M.K., Nor Shaari, M. and Al-Shibami Ahmed, H. (2011). Locational Related Determinants of Foreign Direct Investment in Yemen: Dunning's Eclectic Paradigm Perspective. Australian Journal of Basic and Applied Sciences, 5(8), pp.394-404.

5. Al-Shawaf, A.M.K. \& Almsafir, M. K. (2016).Economic globalization: role of inward and outward FDI with economic growth-Evidence from Malaysia.Journal of Business and Retail Management Research, Vol.10 Issue 2, pp.64-74.

6. Bari, I. (2005). Globalizarea economiei, Bucuresti: Editura Economica.

7. Catana, A. (2011).Multinational Corporations and Foreign Direct Investments in Romania. Effects on the Romanian Trade. The Annals of the University of Oradea, Economic Sciences, Issue 2, pp. 148-156.

8. Dreher, A. (2006). Does Globalization Affect Growth? Empirical Evidence from a new Index Globalization. Applied Economics, 38 (10), pp.1091-1110.

9. Dreher, A., Gaston, N., Martens, P. (2008). Measuring Globalization-Gauging its Consequence. New York: Springer.

10. Fadhil, M.A. and Almsafir, M.K.(2015). The Role of FDI Inflows in Economic Growth in Malaysia (Time Series: 1975-2010). Procedia Economics and Finance, 23, pp.15581566.

11. Farshid, P. Ali, S. and Gholamhosein, S. (2009). The impact of foreign direct investment and trade on economic growth-Taking China, Korea, Malaysia, Philippines \& Thailand for example. China-USA Business Review, 8(12), pp.37-43.

12. Hailu, Z.A. (2010). Impact of Foreign Direct Investment on Trade of African Countries. International Journal of Economics and Finance, 2(3), p.p122-133.

13. Heimann, B. (2003). Tax incentives for Foreign Direct Investment in the Tax Systems of Poland, the Netherlands, Belgium and France. Available at: http://www.iwim.unibremen.de/publikationen/pdf/b074.pdf Accessed 30 June 2016.

14. Huidumac-Petrescu, C.; Joja, R.M.; Hurduzeu, Gh.; Vlad, L.B. (2011). Foreign Direct Investments Expansion - Essential Globalization Factor. Theoretical and Applied Economics, Volume XVIII, No. 1 (554), pp. 163-172.

15. Isac, C.; Dura, C.; Ciurlau, F.C. (2011). The expansion of FDI flows-a major factor of globalization. Annals of University of Petrosani, Economics 11(4), pp.139-150.

16. Kahai, S.K. \&Simmons, W. (2005).The impact of Globalization on income inequity. Global Business and Economics Review, Vol.7, No.1, pp.1-15.

17. KOF, Index of Globalization. Available at http://globalization.kof.ethz.ch/ Accessed 30 June 2016. 
Dima S. (2016)

Globalisation, trade openess and foreign direct investment in Romania

18. Kornecki, L. \& Rhoades, D. (2007). How FDI facilitates the globalisation process and stimulates economic growth in CEE. Journal of International Business Reserch, Vol.6, No.1, pp.113-126.

19. Méon, P.G. and Sekkat, K.(2007). Revisiting the relationship between governance and foreign direct investment. Brussels Economic Review, 50(1), pp.41-61.

20. Moghaddam, A.A. and Redzuan, M.R. (2012). Globalization and Economic Growth: A Case Study in A Few Developing Countries (1980-2010). Research in World Economy, 3(1), p.p54-62.

21. Murariu, I.A. (2011) Cauzele si implicatiile procesului globalizarii economiei mondiale. Studia Universitatis "Vasile Goldis" Economic Series, Anul 21 Partea a 2-a, pp.329333.

22. Mutascu, M. and Fleischer, A.-M. (2011). Economic Growth and Globalization in Romania.World Applied Sciences Journal, 12 (10), pp.1691-1697.

23. Neagu, O. (2014). How much does globalisation affect the income inequality in Romania?. Studia Universitatis" Vasile Goldis" Arad, Economics Series, Vol. 24, Issue 4, pp.76-83.

24.Pradhan, R.P.(2010). Trade Openness and Foreign Direct Investment in India: The Globalization Experience. IUP Journal of Applied Finance, 16(3), p.26-43. 